Review Article

\title{
DNA repair diseases: What do they tell us about cancer and aging?
}

\author{
Carlos FM Menck and Veridiana Munford \\ Departamento de Microbiologia, Instituto de Ciências Biomédicas, Universidade de São Paulo, São Paulo, \\ SP, Brazil.
}

\begin{abstract}
The discovery of DNA repair defects in human syndromes, initially in xeroderma pigmentosum (XP) but later in many others, led to striking observations on the association of molecular defects and patients' clinical phenotypes. For example, patients with syndromes resulting from defective nucleotide excision repair (NER) or translesion synthesis (TLS) present high levels of skin cancer in areas exposed to sunlight. However, some defects in NER also lead to more severe symptoms, such as developmental and neurological impairment and signs of premature aging. Skin cancer in XP patients is clearly associated with increased mutagenesis and genomic instability, reflecting the defective repair of DNA lesions. By analogy, more severe symptoms observed in NER-defective patients have also been associated with defective repair, likely involving cell death after transcription blockage of damaged templates. Endogenously induced DNA lesions, particularly through oxidative stress, have been identified as responsible for these severe pathologies. However, this association is not that clear and alternative explanations have been proposed. Despite high levels of exposure to intense sunlight, patients from tropical countries receive little attention or care, which likely also reflects the lack of understanding of how DNA damage causes cancer and premature aging.
\end{abstract}

Keywords: xeroderma pigmentosum, ultraviolet, DNA damage, oxidative stress, DNA repair.

\section{Introduction}

During evolution, the stability of genetic material plays a fundamental role in the maintenance of life. The equilibrium between the benefits of changes in the blueprint of life, which facilitates diversity, and the perpetuation of genetic information is fundamental for evolution. In multicellular organisms, this equilibrium faces other problems, such as the transmission of genetic instability to new generations of cells (gametic cells) and components of the organism structure (somatic cells). For example, in humans, genetic instability in somatic cells has been directly associated with the formation of cancer, and cells may die to avoid these deleterious effects. However, cell death may trigger processes associated with organism aging.

The long DNA molecules, that compose genetic material, are not stable. Exogenous factors (such as ultraviolet, UV, from daylight), chemical products (such as smoke, pollution, and natural and artificial drugs), endogenous agents, and normal byproducts of cell metabolism, including radical oxygen species (ROS) generated during respiration, constantly threaten DNA stability (Andressoo and Hoeijmakers, 2005; Iyama and Wilson 3rd, 2013). These

Send correspondence to Carlos F.M. Menck. Departamento de Microbiologia, Instituto de Ciências Biomédicas, Universidade de São Paulo, Av. Prof. Lineu Prestes 1374, 05508-900 São Paulo, SP, Brazil. E-mail: cfmmenck@usp.br. agents damage the DNA molecule, and cells must attend to these DNA lesions to properly survive and evolve. To maintain the equilibrium necessary for survival and diversity, evolution has equipped all living beings with the tools to either remove or tolerate DNA damage. In general, these tools, called DNA repair mechanisms or pathways, take care of the DNA molecule, avoiding the deleterious consequences of the different types of DNA lesions. DNA repair pathways are highly conserved in nature, indicating these mechanisms are as old as life on Earth.

The importance of DNA repair mechanisms is dramatically demonstrated in certain human syndromes that are characterized as being defective in DNA repair processes, exacerbating the clinical effects of the unrepaired DNA damage, such as xeroderma pigmentosum (XP). Most XP patients are defective in nucleotide excision repair (NER), which removes DNA lesions induced by the UV component of sunlight, although some XP patients have also shown defects in the replication of UV-damaged DNA. The main clinical symptoms of XP patients include the high frequency of tumors in the exposed areas of skin, indicating a clear causative relationship between unrepaired DNA lesions, genetic instability (XP cells are highly mutable) and cancer. Some XP patients, however, present more severe clinical phenotypes, including developmental problems, neurodegeneration and premature aging (Lehmann, 2003; Lehmann et al., 2011; DiGiovanna 
and Kraemer, 2012). These severe symptoms have been associated with other syndromes, such as Cockayne syndrome (CS), that have also been shown to be defective in NER (see below) (Cleaver et al., 2013). The reasons for these more severe clinical aspects are still not clearly understood, although, in general, these symptoms implicate unrepaired DNA damage in the process of neurological degeneration and aging. In this work, we discuss the historical data associated with the lack of DNA repair and its deleterious consequences on the human organism, focusing on the scientific contribution of the findings in XP and NER-related human diseases associated with cancer and aging. Other human syndromes, such as ataxia telangiectasia, Fanconi Anemia, Werner syndrome, among others, associated with defects in other DNA repair pathways or DNA damage responses, also show symptoms associated with cancer, aging and developmental and neurological problems. These syndromes also support the relevance of DNA damage in these processes and also indicate that different DNA repair pathways correspond to networks that protect the genome. However, these syndromes will not be reviewed here, and the reader is invited to search for more information in other recent reviews (Kim and D'Andrea, 2012; Knoch et al., 2012; Marinoglou, 2012; Moraes et al., 2012; Shiloh and Ziv, 2013). Moreover, mouse models with defective DNA repair mimic some human clinical phenotypes, including many aging symptoms. Indeed, animal models have provided several clues and numerous data to support this debate, but this information will only be commented in this work when they are applied directly to some aspects of DNA repair. For more information concerning animal models, the reader is referred to recent reviews (Diderich et al., 2011; Goss et al., 2011; Niedernhofer et al., 2011; Gredilla et al., 2012; Jaarsma et al., 2013).

Most studies concerning XP patients have been performed in developed countries (North America and Europe) at high latitudes, with the exception of African-born patients studied in Europe. The doses of UV in the sunshine at high latitudes are low compared with tropical countries, such as Brazil and other Latin American countries. Thus, although exposed to a more aggressive environment, the patients in these countries have primarily remained unattended, except for a few recent studies. More than just identifying gene mutations that affect XP patients in tropical countries, these studies have contributed to the understanding of how DNA repair defects correlate with genotype-phenotype associations. A prospective approach using next-generation sequencing to diagnose the mutations of XP and NER-related patients may help these individuals and their families to address the disease and may eventually contribute with new data for understanding how DNA lesions lead to cancer, neurodegeneration and/or aging.

\section{$\mathrm{XP}$ and the Discovery of Molecular Defects in DNA Repair}

$\mathrm{XP}$ is a rare autosomal recessive disease; most patients exhibit high sensitivity to sunlight. The patients present strong skin freckle-like pigmentation and lesions in areas exposed to sunlight. These skin-aging symptoms may also appear as precancerous skin lesions, such as actinic keratosis, and most XP patients, when unprotected, develop skin cancer (non melanoma and melanoma) before the age of 10. Compared with the entire population, XP patients have a 10,000-fold increase in the incidence of non-melanoma skin tumors and a 2,000-fold increase in the incidence of melanoma before the age of 20 (Kraemer et al., 1994). Certain exposed areas of the face, such as the eyes and mouth, may also suffer from the sensitivity to sunlight and develop lesions, including tumors. Many XP patients present photophobia. The frequency of internal tumors also shows a 10-fold increase in XP patients. Interestingly, 20 to $30 \%$ of XP patients develop progressive neurological problems (DiGiovanna and Kraemer, 2012; Sepe et al., 2013). The estimated incidence of XP in the population varies: 1 per 250,000 in USA (Robbins et al., 1974) and 1 per 450,000 in Western Europe (Kleijer et al., 2008). In some places, such as Japan and North Africa, the incidence of XP may be higher (1 per 20,000), likely reflecting the high prevalence of certain mutations due to founder effects (Hirai et al., 2006; Soufir et al., 2010).

XP was the first syndrome associated with a defect in the DNA processing pathway. The dermatologists Moritz Kaposi (Hungarian) and Ferdinand Ritter von Hebra (Austrian) provided the first clinical description of XP patients (Hebra and Kaposi, 1874). By the nineteenth century, the syndrome was correctly considered as an inherited disease and was associated with sunlight exposure. This condition was referred to as xeroderma pigmentosum (for dry and pigmented skin, from the Greek words xero and derma; and Latin word pigmentosum). Subsequently, DeSanctis and Cacchione (1932) described a more severe form of XP, DeSanctis-Cacchione syndrome (DSC), which was associated with neurological degeneration.

In 1968, James Cleaver identified the molecular defects associated with XP, showing that XP cells were hypersensitive to UV light and unable to perform unscheduled DNA synthesis (UDS) after UV irradiation (Cleaver, 1968). As described below, UDS is part of the NER pathway after the removal of DNA damage. This outstanding discovery provided the first evidence that a cell defect in DNA metabolism is associated with a clinical phenotype, explaining, in part, the high photosensitivity of XP skin.

Soon, clever experiments, fusing cells from different patients, facilitated the identification of complementation groups (De Weerd-Kastelein et al., 1972). Specifically, if the fusion of two different cells resulted in the restoration of UDS, then the cells were deficient in different comple- 
mentation groups or genes. If the fusion did not restore UDS, the cells were deficient in the same gene and belonged to the same complementation group. These types of experiments led to the classification of XP in seven different complementation groups (XP-A to XP-G), corresponding to seven genes with mutations that might result in XP. Years later, the cells of some XP patients, however, were demonstrated as NER proficient and capable of UDS. The inability of these cells to replicate DNA after UV irradiation (daughter-strand repair) indicated other problems in terms of dealing with DNA lesions, although these cells maintained the ability to remove these lesions (Lehmann et al., 1975). These cells were referred to as XP variants (XP-V). The subsequent identification of DNA polymerase activity associated with the XPV protein (DNA polymerase eta) confirmed that XP-V patients are deficient in translesion synthesis (TLS) (Kannouche and Stary, 2003; Masutani et al., 2008).

The cells from all XP patients show an increased frequency of mutagenesis after exposure to UV light that is correlated with molecular defects in DNA damage processing, leading to mutagenic consequences in the cells and increased tumorigenesis in patients. Thus, these correlations were the first clear demonstration that DNA damage and mutations cause cancer (van Steeg and Kraemer, 1999; Cleaver, 2000).

\section{Other NER-Defective Genetic Disorders}

As described above, approximately 20 to $30 \%$ of XP patients also develop progressive neuronal impairment and premature aging. The symptoms include hearing loss, swallowing difficulties and mental retardation. Neuronal degeneration has been identified as the primary cause for these clinical features; however, in some cases, severe developmental problems, such as growth retardation and microcephaly, have been observed. These more severe symptoms are associated with the DSC as well as XP in combination with Cockayne syndrome (CS), and this combined disorder is referred to as $\mathrm{XP} / \mathrm{CS}$. Indeed, CS is a rare autosomal recessive disorder, first described in 1936 (Cockayne, 1936). CS patients suffer from sun sensitivity and exhibit many premature aging features, including cachectic dwarfism, kyphosis, arrested sexual development, thin hair, subcutaneous fat loss, osteoporosis and a characteristic "bird-like" face (deep sunken eyes and prominent ears). The neurological symptoms include microcephaly, progressive hearing and visual loss, progressive ataxia, delayed psychomotor development, and mental retardation. These features reflect dysmyelination and neurodegeneration, and the brain shows prominent calcification (Iyama and Wilson 3rd, 2013; Jaarsma et al., 2013). Similar to XP cells, initial studies with CS cells revealed hypersensitivity to UV irradiation, although normal levels of UDS and daughter strand repair were observed (Schmickel et al., 1977; Andrews et al., 1978a). A few years later, the nature of the molecular repair defect in CS cells was identified as a failure to recover RNA synthesis after DNA damage induced through UV-irradiation (Mayne and Lehmann, 1982), suggesting a problem with the transcription of a damaged template. Importantly, this RNA synthesis impairment was used to identify two different complementation groups for CS cells (CS-A and CS-B) and an independent complementation group in XP/CS cells (associated with the XP-B group) with similar molecular defects (Lehmann, 1982). This important discovery revealed two NER sub-pathways associated with global genome repair (GGR) and RNA transcription (transcription coupled repair-TCR).

Subsequently, other genetic disorders were described as the direct results of NER defects. In some cases, the patients present neuronal and/or developmental problems, such as trichothiodystrophy (TTD), where the patients show features similar to CS (short stature, skeletal abnormalities, impaired intelligence, decreased fertility, and photosensitivity) and fragile and brittle hair due to the sulfur-deficiency and reduced levels of cysteine-rich matrix proteins (Stefanini et al., 2010). Cerebro-oculo-facio-skeletal syndrome (COFS) is considered to be a severe form of CS, with symptoms appearing at birth (Suzumura and Arisaka, 2010), and XPF-ERCC1 progeroid (XFE) syndrome is associated with renal and liver abnormalities (Niedernhofer et al., 2006). However, UV-sensitive syndrome (UVSS) has been described as a mild genetic disorder leading to skin photosensitivity (Spivak, 2005; Oh and Spivak, 2010). Curiously, all these syndromes show skin photosensitivity and defects impairing NER, but among their clinical features, there has been no report of increased cancer frequency.

With the advent of DNA recombinant techniques in the 1980s, many research groups have attempted to clone the mutated genes in these NER-related diseases, although this proved to be a difficult task because DNA transfection in human cells was not trivial. In the 1990s, however, the use of mutated rodent cells deficient for different DNA repair pathways facilitated the cloning of XP genes, contributing to the understanding of the mechanisms of NER and TLS, described in more detail below. As human genes showed cross complementation with rodent cells, these genes have been, in many cases, referred to as ERCC (for excision cross-complementing) genes (Boulikas, 1996). The human genes identified in NER-related diseases and TLS, with their chromosomal locations and summarized functions, are shown in Figure 1.

\section{The XP Molecular Defects: Removing DNA Damage via NER or Replicating Damaged DNA through TLS}

Classical XP (XP-A to XP-G) cells are defective in the removal of DNA damage through NER, and XP-V cells tolerate the lesions by replicating damaged templates 


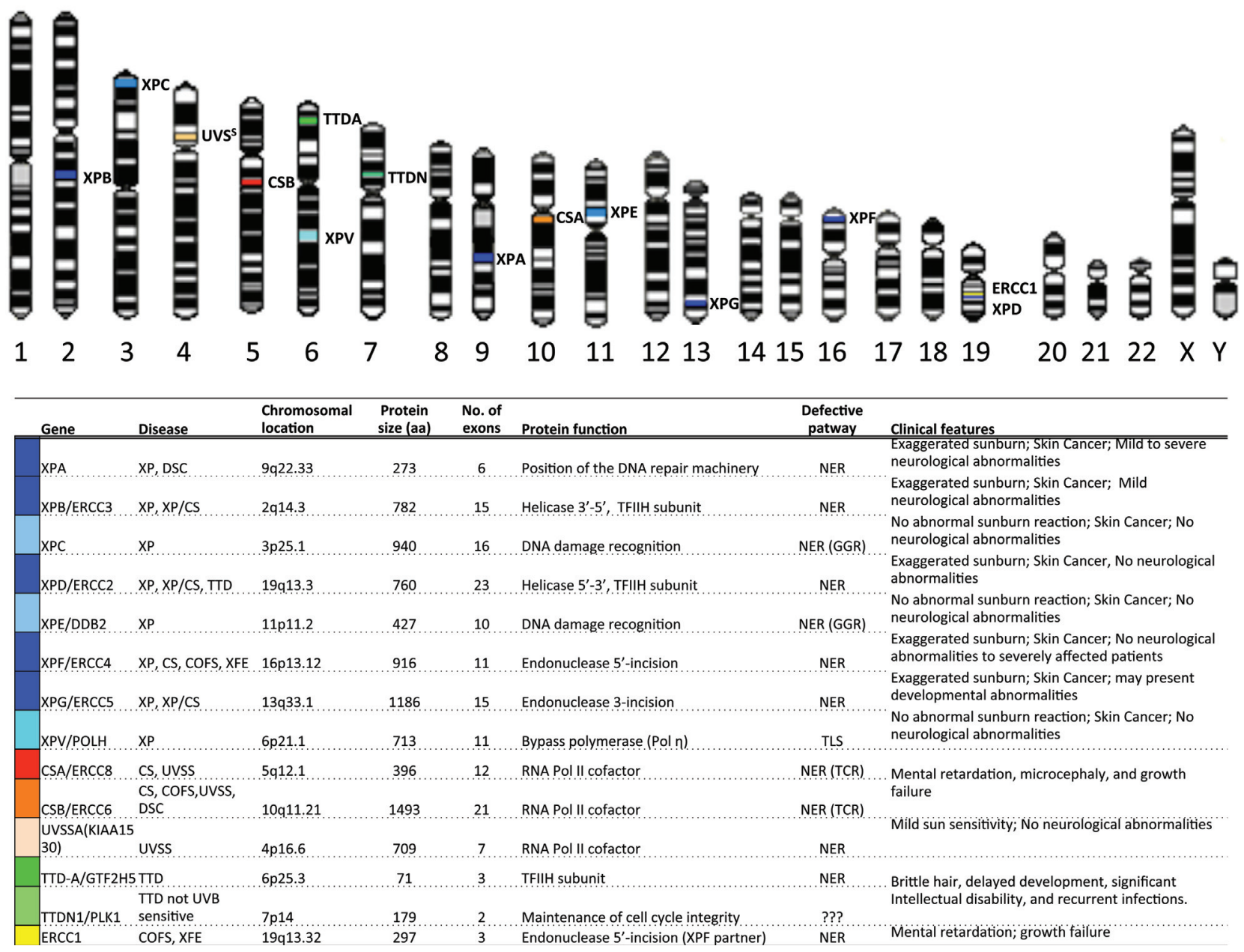

Figure 1 - Human chromosomal location and general description of the genes encoding proteins involved in nucleotide excision repair (NER) and translesion synthesis (TLS). Mutations in these genes cause human syndromes, listed in the table.

through TLS. These mechanisms are schematically represented in Figures 2 and 3.

Although NER was first described for the removal of UV-induced lesions (such as cyclobutane pyrimidine dimers, CPDs, and 6-4 pyrimidine-pyrimidone, 6-4PPs), this pathway is recognized as a versatile and flexible mechanism. Specifically, NER removes structurally unrelated bulky lesions, which promote DNA distortions in the double helix. These lesions include DNA adducts or intrastrand crosslinks induced by chemical agents (such as benzo(a)pyrene, a product of tobacco smoke, and cisplatin, an anticancer chemotherapeutic drug) that react with DNA or injuries induced by endogenous agents, such as lesions generated by oxidation through ROS produced in the cells as a potential byproduct of respiration. There are more than 30 proteins that act in a sequential and concerted manner to remove DNA damage (Costa et al., 2003). Notably, defective activity in seven of these proteins (from XPA to XPG) may result in a clinical XP phenotype. Moreover, the defective activity of CSA and CSB may result in severe CS symptoms (Jaarsma et al., 2013). Other NER proteins have also been recently described, where mutations cause NER syndromes: TTDA/p8 (part of TFIIH complex, Giglia-Mari et al., 2004), causing TTD; ERCC1 (partner of XPF endonuclease), causing XFE, CS and COFS (Suzumura and Arisaka, 2010, Kashiyama et al., 2013); UVSSA causing UVSS (Schwertman et al., 2012; Zhang et al., 2012).

NER can be summarized as having four sequential steps, including i) lesion recognition, ii) unwinding the damaged double helix, iii) cleavage and excision of the damaged strand and iv) filling the gapped molecule, followed by DNA synthesis and final ligation (Figure 2). TLS through XPV also facilitates tolerance of UV-induced photoproducts, such as CPDs, and other types of DNA damage induced through other DNA damaging agents (Figure 3).

Two different sub-pathways have been implicated in the recognition step of NER, depending on the location of the lesion. The global genome repair (GGR) sub-pathway involves the recognition of DNA lesions throughout the genome, and it depends on the XPC/HR23B protein complex as the primary DNA damage detector. For some types of le- 


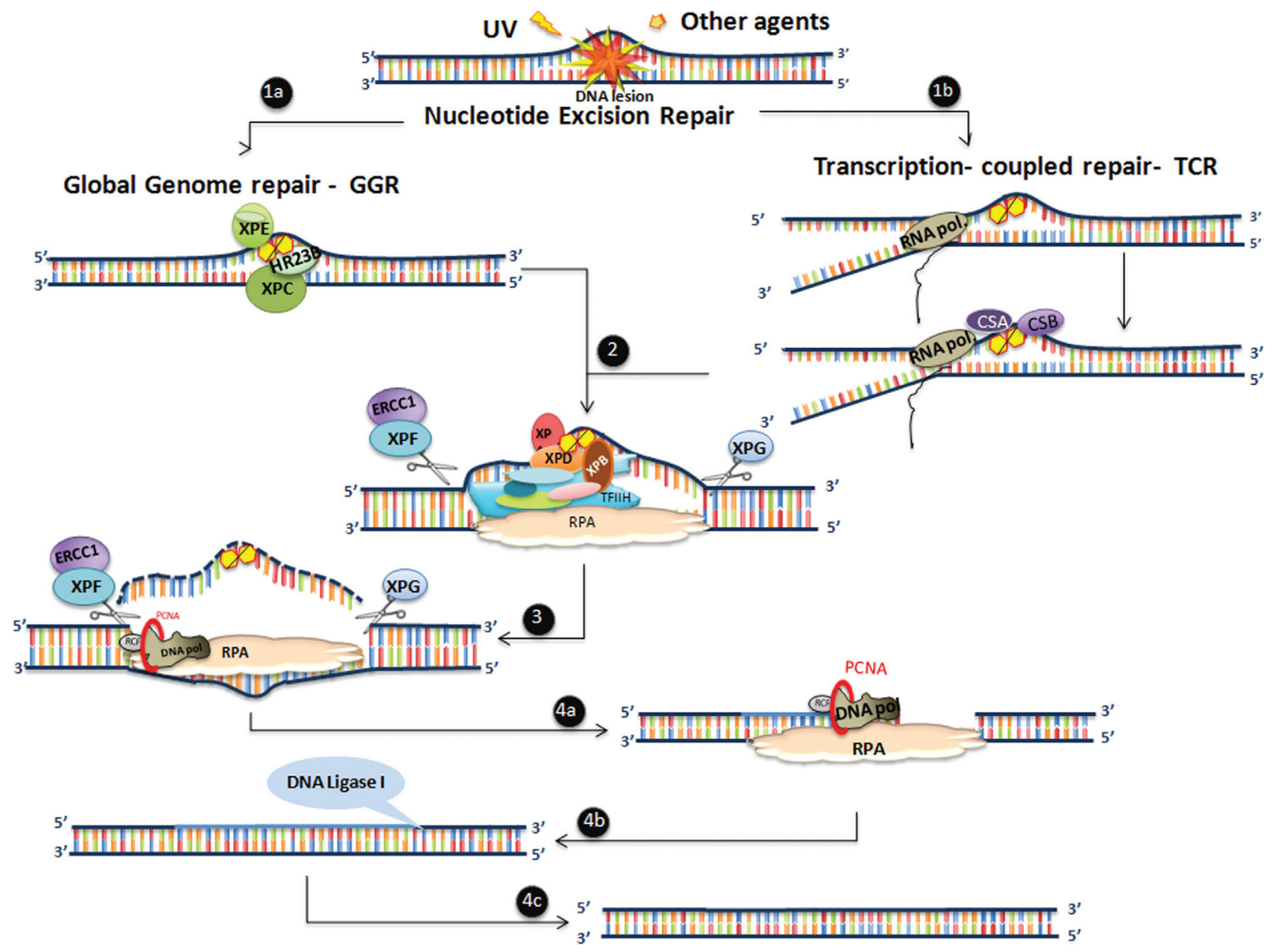

Figure 2 - Schematic representation of nucleotide excision repair (NER): the proteins associated with human diseases are highlighted. The downstream NER pathway and each of the sub-pathways (GGR and TCR) for lesion recognition are indicated, showing the different steps for DNA lesion removal in an error-free manner.

sions, such as CPDs, the damaged DNA binding (DDB) complex (composed of two proteins, including XPE) is required for improving the efficiency of damage recognition and removal. The transcription-coupled repair (TCR) subpathway acts on the transcribed strand of actively expressed genes. The existence of this sub-pathway was first observed when DNA damage was not homogeneously removed from the genome of mammalian cells, and the preferential repair of CPD lesions was detected in active genes (Bohr et al., 1985). Subsequently, this preferential repair system was demonstrated as being selective for the transcribed strand, implicating the transcription machinery in the recognition of DNA damage (Mellon et al., 1987). Subsequent studies with CS cells demonstrated that these cells were deficient in the preferential repair of active genes (Mullenders et al., 1988; Venema et al., 1990). Indeed, the CSA and CSB proteins are important players in the recognition of DNA lesions in the TCR pathway, triggered by the blockage of RNA polymerase II during transcription.

The next step, common to both GGR and TCR subpathways, is initiated through the recruitment of the tran- scription factor TFIIH, a multiprotein complex, which includes XPB and XPD proteins, 3'-5' and 5'-3', respectively, ATP-dependent DNA helicases. This complex unwinds $\sim 30$ bp at the damaged DNA site, which is covered by a single RPA (from Replication Protein A) complex (a single-stranded DNA binding complex, composed of three sub-unities). RPA and XPA proteins are likely involved in the correct three-dimensional assembly of the NER machinery prior to the endonucleolytic cleavage step. XPG proteins and the XPF/ERCC1 complex are the main endonucleases that nick DNA at both sides, some nucleotides away from the damage. Although XPG is required for $\mathrm{XPF} / \mathrm{ERCC} 1$ activity, this heterodimer makes the initial 5'-incision, followed by the XPG incision at the 3' side of the lesion (Fagbemi et al., 2011). The final step of NER is the gap filling through repair synthesis. Replicative DNA polymerases (Pol $\delta$ and Pol $\varepsilon$ ) use the 3'-hydroxyl extremity, generated by the XPF/ERCC1 incision, as a primer to synthesize DNA at the 30-nucleotide-gap. The resulting nick at the 5' end of the gap is sealed through DNA ligase I 


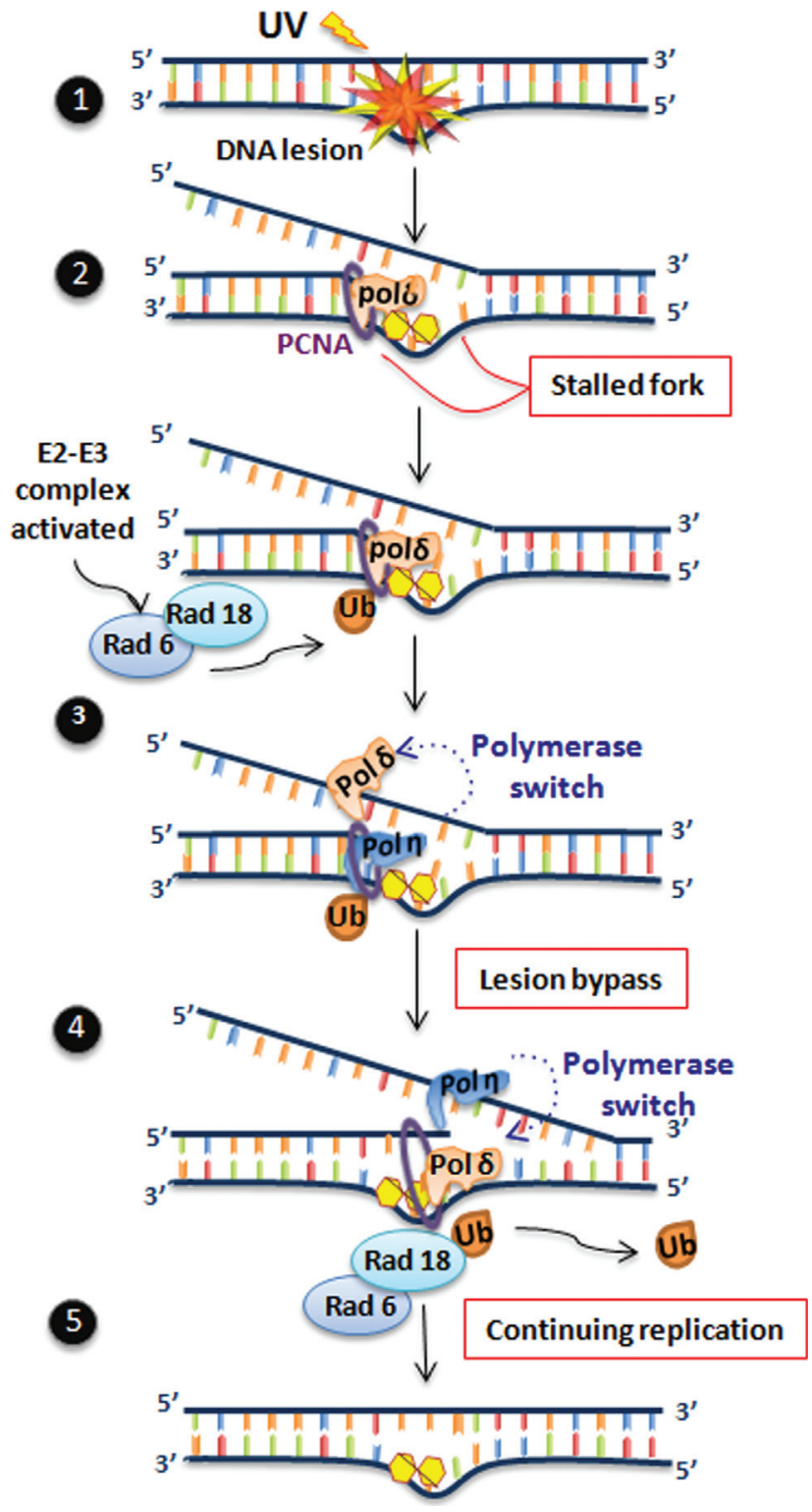

Figure 3 - Schematic representation of translesion synthesis (TLS) by Pol $\eta$. The replication fork is blocked by DNA damage, and after a series of events (including the monoubiquitination of PCNA), a polymerase switch provides DNA polymerase eta $(\mathrm{XP}-\mathrm{V})$ with an opportunity to bypass the lesion. In this figure, only one strand (leading strand) is represented. At the end of the process the lesion remains in the DNA, but the replication of this molecule can proceed.

or III (Moser et al., 2007). Thus, normal NER restores the original DNA molecule in an error-free manner.

The replication machinery may encounter unrepaired DNA lesions, potentially resulting in a blockage in DNA synthesis, as replicative DNA polymerases do not have the capacity to use damaged templates. This important blockage may lead to the collapse of the replication fork, production of double-strand breaks, and, ultimately, cell death (Batista et al., 2009). To tolerate DNA damage in replicating templates, nature has evolved several alternative DNA polymerases that replace the replicating polymerases (also termed polymerase switching) and replicate the lesions through TLS (Figure 3). Among the many alternative DNA polymerases described during the last two decades (Sale et al., 2012; Sale, 2013), XPV protein, or DNA polymerase eta (Pol $\eta$ ), deserves special attention. Mutations in this DNA polymerase have been implicated in the human syndrome XP. The defective activity of this protein in XP-V cells results in sensitive to UV-light or cisplatin treatment, particularly when the cells are transformed with SV40 or HPV, inhibiting the activity of p53 protein. These cells are also highly mutable after UV-light, which explains the high incidence of skin tumors in XP-V patients. Pol $\eta$ bypasses certain types of lesions, such as the CPDs induced through UV-light, although the activity of this polymerase through 6-4PPs is controversial. The lack of Pol $\eta$ leads to a strong blockage of the replication forks in XP-V cells, but replication can still recover through the action of other alternative polymerases (Kannouche and Stary, 2003; Quinet et al., 2014). Interestingly, Pol $\eta$ is an error prone DNA polymerase, showing reduced replication fidelity. However, this polymerase seems is capable of bypassing thymidine CPDs correctly through the insertion of adenosines in the daughter strand. Thus, the increased mutagenesis observed in UV-irradiated XP-V cells may reflect the activities of other polymerases that replicate this lesion in an error prone manner (Kannouche and Stary, 2003; Masutani et al., 2008).

\section{DNA Damage and Repair vs. Cancer}

Skin photosensitivity is a common clinical feature of all patients showing defective NER responses. The increased sensitivity to UV-light is also observed in cells from XP, CS, TTD, or UVSS patients. Thus, the defective removal of UV photoproducts likely results in this photosensitivity (Lehmann, 2003; Oh and Spivak, 2010). However, although these syndromes reflect defects on the same DNA processing pathway, apart from photosensitivity, they are clinically highly heterogeneous, including increased carcinogenesis, and more severe clinical features, such as abnormal development, neurodegeneration and premature aging. This clinical heterogeneity raises several unanswered questions concerning how unrepaired DNA damage leads to a plethora of different symptoms.

The highly increased mutagenesis induced by UV irradiation in XP cells is well correlated with the high levels of skin cancer observed in XP patients for all XP complementation groups, including NER-defective, and TLSdefective (Figure 4). Indeed, UV-induced signature mutations were observed in specific tumor suppressor genes (such as p53 and patched) in skin tumors from XP patients, demonstrating the causal role of unrepaired lesions and mutations in the formation of tumors in these patients (Dumaz et al., 1993; Bodak et al., 1999; D'Errico et al., 2000; Giglia-Mari and Sarasin, 2003). Even internal tumors observed in XP patients carry mutations provoked by unre- 


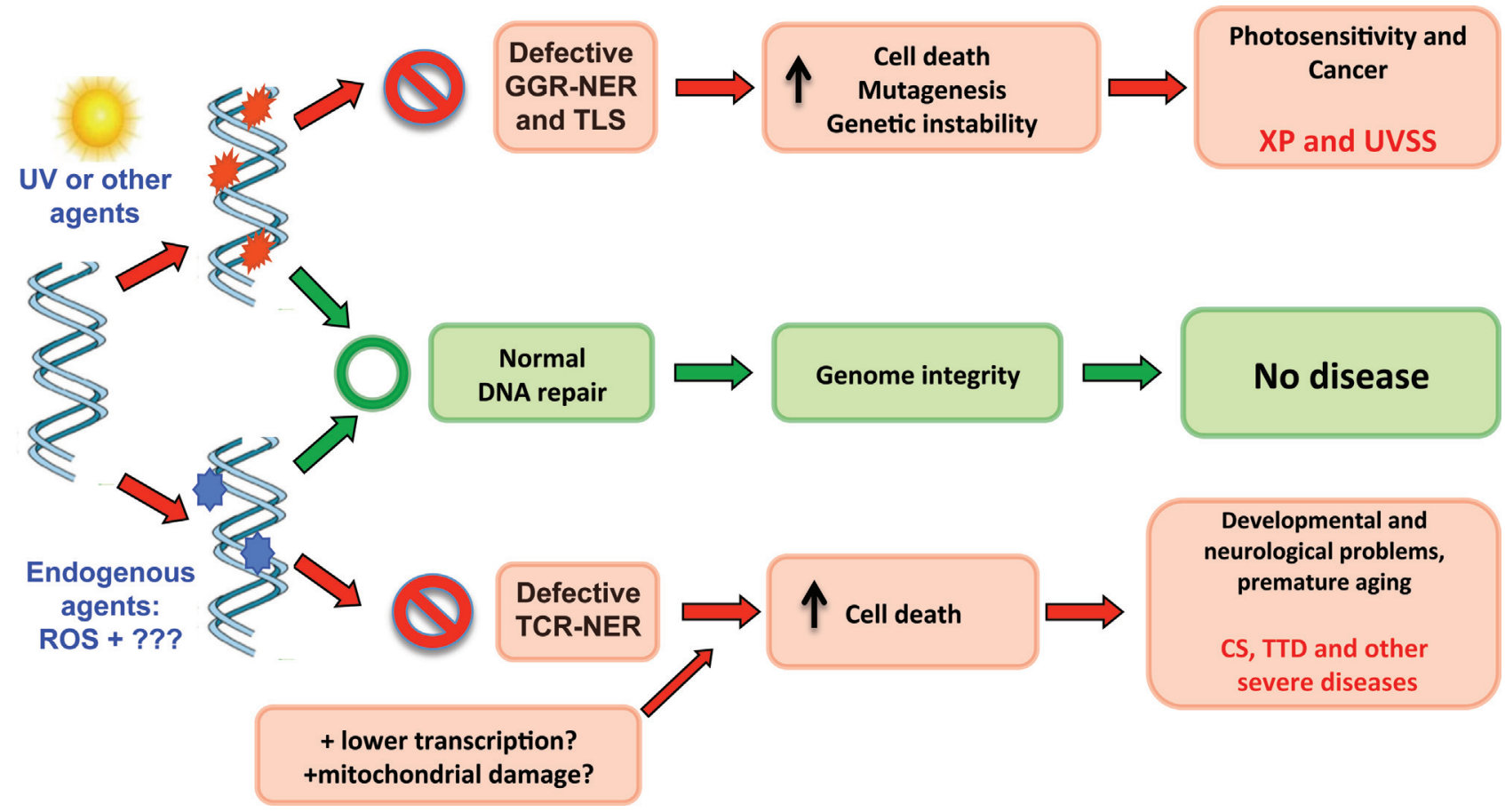

Figure 4 - The consequences of DNA damage and how defective NER and TLS may explain certain clinical phenotypes. Different types of DNA damage can be induced by a variety of endogenous and exogenous agents. NER removes several of these lesions and TLS helps to replicate them, aiming maintenance of the genome stability, and guaranteeing normal cell proliferation, and normal human life (represented in green). When these mechanisms fail, errors in DNA replication increase mutagenesis and genetic instability, resulting in higher photosensitivity (observed in UVSS and XP patients) and risk of cancer development (observed in XP patients). Defective GGR-NER and TLS better explain these phenotypes (in red, superior part of the figure). Alternatively, endogenous DNA damage (including those induced by ROS) may disturb the transcription and/or cause replication blockage, leading to cell death, thus defective TCR-NER better explain the more severe phenotypes (including premature aging) of XP/CS, CS and other syndromes. Other effects, such as impaired transcription or damaged mitochondria may also be involved in these phenotypes (in red lower part of the figure).

paired lesions, likely originating from oxidative stress (Giglia et al., 1998).

Thus, there are clear indications that unrepaired DNA damage induces mutations, and these mutations cause cancer. Nevertheless, the lack of tumors in CS and TTD patients is puzzling. Although the cells from CS patients are defective in a sub-pathway of NER (TCR), the cells from these patients (Parris and Kraemer, 1993) and rodent cells with mutations in the CSB homolog (Vreeswijk et al., 1998) show increased mutations after UV irradiation. Moreover, mouse models defective for CSA and CSB show skin cancer predisposition after UVB irradiation (van der Horst et al., 1997, 2002), unlike their human counterparts. As GGR is more efficient in human cells compared with rodent cells (Hanawalt, 2001), this sub-pathway could protect CS patients from developing skin tumors. Alternatively, it has been proposed that CS cells have a strong signal for cell death after DNA damage, likely reflecting higher levels of transcription blockage (McKay et al., 2001), which may have a reverse effect on cancer development, as dead cells cannot induce cancer. However, XP-A cells are also highly sensitive to DNA lesions, but XP-A patients always develop skin tumors. Notably, the lifetime of severely affected CS, TTD, COFS and XFE patients is typically short and may require living indoors (due to severe clinical fea- tures), reducing their exposure to sunlight and the probability of developing tumors.

Until recently, most mutation studies have investigated base substitution and small point mutations, deletions and insertions, although certainly larger changes in the DNA sequence, including gross rearrangements, copy number variations and chromosomal anomalies and other types of genomic instabilities, are affected by unrepaired DNA damage, representing known alterations in human cancer (Amiel et al., 2004). Moreover, even with clear evidence of sunlight being responsible for skin cancer, many questions remain concerning what is the part of the spectrum acting in tumorigenesis, either in XP patients or the normal population. Although the results strongly suggest a role for CPDs, the main lesion induced by UVB (280-320 $\mathrm{nm})$, in skin carcinogenesis, this type of lesion is also generated after UVA (320-400 nm) irradiation, and other lesions induced by this spectrum of sunlight should also be considered (Douki et al., 2003; Cadet et al., 2012; Schuch et al., 2013). Indeed, a recent study implicated an important role for both CPDs and 6-4PPs in the biological consequences of UVA light in XP cells (Cortat et al., 2013). Skin tumors are the most frequent types of cancer in human populations, particularly in countries near the tropics; thus, a detailed understanding of how these cancers are induced 
through exposure to sunlight is highly relevant to the general public health. Further investigations with XP patients and XP cells can provide important contribution to this field.

\section{Unrepaired DNA Damage and the Aging Process}

Concerning other symptoms, such as developmental problems, neurological abnormalities and premature aging, observed in more severely affected XP patients and other NER-related syndromes (such as CS, COFS, TTD and XFE), the causal effects remain far from being understood. This puzzling question was first raised in the 1970s, when the UV-survival of XP cells from several complementation groups were compared to understand the neurological abnormalities (Andrews et al., 1976, 1978b; Kraemer et al., 1976). In general, the cells from patients with more severe symptoms were more UV sensitive than those with no neurological abnormalities. Similar results were soon described for CS-derived cells, indicating the sensitivity of these cells to UV damage (Andrews et al., 1978a). Ultimately, it was concluded that extremely inefficient DNA repair could not protect these neurons (or supporting glial cells) from DNA damage in some of the patients, and the neurons would die prematurely.

Interestingly, in the first reports, XP-C patients were already noticed as less affected by the severe symptoms. Indeed, XP patients mutated in the XPC, XPE (both participate in the initial steps of GGR pathway of NER, see Figure 2) and XPV (TLS, Figure 3) genes present symptoms associated with skin lesions, but not affecting the nervous system. This observation indicates that defects in the GGR sub-pathway of NER and TLS through Pol $\eta$ could explain the increased tumorigenesis observed in the skin of these patients, which prevents mutagenesis, as described above. Thus, patients with mutations in these genes and other genes (XPA, XPB, XPD, XPF and XPG) that participate downstream in the GGR sub-pathway may present only XP phenotypes associated with skin lesions, which may be avoided by preventing sun exposure.

On the other hand, TCR impairment is clearly associated with more severe symptoms in NER-related syndromes (Figure 4). The high levels of cell death of TCR impaired cells in response to DNA damage, likely triggered by a blockage in RNA transcription, have been associated with the severe symptoms in CS patients (McKay et al., 2001). A similar explanation may also be associated with $\mathrm{XP} / \mathrm{CS}$, COFS, TTD, and XFE syndromes. However, the nature of the DNA damage resulting in this increased cell death remains unknown. Endogenously induced lesions generated by free radicals, including ROS, are the strongest candidates for these effects. Indeed, CS-B cells have been demonstrated as deficient in the repair of DNA damage generated through oxidative stress under many circum- stances. Initially, CSB was shown to be important for the removal of 8-oxoguanine (8-oxoG), a known lesion produced by oxidative stress, in human cells irradiated with ionizing radiation (Tuo et al., 2001, 2003). Subsequently, this effect was also described for CS-A human primary fibroblasts (D'Errico et al., 2007). Mouse models defective in CSB protein were shown to accumulate oxidized purine modifications (8-oxoG and (5'S)-8,5'-cyclo 2'-deoxyadenosine) in certain tissues with age (Osterod et al., 2002; Kirkali et al., 2009). More recently, CS-A and CS-B primary human cells and CS-B reprogrammed iPS cells were shown to have altered metabolic redox balance, with increased levels of intracellular ROS and basal (and induced) levels of DNA damage (Andrade et al., 2012; Pascucci et al., 2012).

Consistent with this model, CS-A and CS-B cells are more sensitive to hydrogen peroxide treatment compared with cells derived from UVSS patients, who present only photosensitivity symptoms. Host cell reactivation after the transfection of damaged plasmids in human cells yields similar results. This approach measures the expression of a reporter gene, and this expression is impaired after DNA damage, which is recovered through DNA repair in the transfected cells. Although both CS-B and UVSS cells are defective in the recovery of UV-irradiated plasmids, only CS-B cells recover gene expression through plasmids carrying oxidized base damage (Spivak and Hanawalt, 2006). Moreover, a UVSS patient was demonstrated to have a specific mutation in the CS-A gene, and cells derived from this patient were highly sensitive to UV irradiation; however, in contrast to CS-A cells from CS patients, these UVSS cells were not sensitive to potassium bromate or other agents that generate oxidative stress (Nardo et al., 2009). Similar results were obtained in XP patients carrying missense mutations in the XPG gene. Specifically, the cells from mildly affected patients (clinically showing only photosensitivity) were sensitive to UV-light but not to the treatment of photoactivated methylene blue (which generates singlet oxygen), in contrast to XP-G/CS cells that were sensitive to this oxidative stress. Host cell reactivation also confirmed that the XPG alleles containing missense mutations fully reactivated the expression of reporter genes from plasmids damaged with photoactivated methylene blue in XP-G/CS deficient cells, while only partial reactivation was obtained in UV-irradiated plasmids (Soltys et al., 2013).

Thus, defective transcriptional repair of DNA damage generated through oxidative stress is associated with more severe clinical features, such as developmental and neuronal abnormalities and premature aging, while the defective repair of UV induced DNA damage is associated with photosensitivity phenotypes (Andressoo and Hoeijmakers, 2005). However, other published data challenge this model: XPC protein has also been implicated in the repair of DNA damage induced through oxidative stress, although XP-C patients present only clinical features associated with 
skin photosensitivity, with no symptoms involving neurological or developmental problems. Human XP-C primary keratinocytes and fibroblasts are hypersensitive to treatment with oxidizing agents and accumulate oxidized DNA damage after oxidant exposure (D'Errico et al., 2006). A similar defect was shown in the host cell reactivation of photoactivated methylene blue damaged adenovirus vectors (Kassam and Rainbow, 2007). The participation of both XPA and XPC proteins in the repair of photoactivated methylene blue-induced DNA damage was also investigated in cells treated with this agent or in the host cell reactivation of damaged plasmids. The results suggest that the NER pathway directly participates in the repair of DNA lesions generated through oxidative stress (Berra et al., 2013). However, live imaging data indicates that proteins that initiate NER (XPC and CSB) are rapidly recruited to sites of the cell nuclei containing oxidized base damage, with the absence of the detectable recruitment of other downstream NER factors. These results indicate that the binding of XPC and CSB to the sites of DNA damage is independent on a further NER reaction (Menoni et al., 2012).

Therefore, as the participation of XPC protein in cell protection from oxidative stress is confirmed, the lack of oxidative stress-mediated DNA damage repair may be necessary but not sufficient to explain the severe pathology of neurological and developmental symptoms and the accelerated aging observed in NER-related syndromes. Further defects are needed to construct these severe symptoms, and many possibilities are being investigated. Thus, two potential hypotheses emerge that may help to understand and eventually answer this question: mitochondrial DNA damage and general deficiency in transcription.

Indeed, the participation of NER factors in mitochondria is gaining support. CS-B protein was shown to stimulate the repair of 8 -oxoG in the mitochondrial DNA (Stevnsner et al., 2002, Aamann et al., 2010). Moreover, CS-B cells are deficient in autophagy, leading to increased oxidative stress and the accumulation of damaged mitochondria. Interestingly, these effects could be reversed through the addition of autophagy stimulators, such as lithium chloride and rapamycin, to the cell culture medium (Scheibye-Knudsen et al., 2012). Moreover, the participation of many of the proteins in TCR in the global transcription machinery may also be important. A general reduction in transcription through RNA polymerase II has been observed in CSB cells (Balajee et al., 1997). The participation of CSB in transcription elongation and TFIIH as an initiation transcription factor should be considered for these "transcription syndromes" (Compe and Egly, 2012; Velez-Cruz and Egly, 2013). The need for the repair of DNA damage to achieve the effects observed in these pathologies has also been questioned, as the defects on transcription through RNA polymerases I and II may solely explain the severe symptoms of CS patients (Brooks, 2013).
Some patient cases still add more confusion to the genetic basis of carcinogenesis and neurological abnormalities resulting from NER defects. Although CS patients do not present skin tumors, at least one case of siblings showing a severe XP phenotype (diagnosed as the DeSanctisCacchione variant of XP) were identified with a missense mutation in the CSB gene (Colella et al., 2000). In contrast, a UVSS patient has been demonstrated as completely null for this same CSB gene (Horibata et al., 2004). The understanding of the molecular basis underlying these clinical phenotypes may help to understand the intricate role of DNA damage and repair in the human pathology of cancer and aging.

\section{XP Under the Tropical Sun}

Although sunlight is much more intense at low latitudes, with higher intensity of UVB light and more severe DNA lesions (Schuch et al., 2012), most studies with XP patients has been performed in Europe, USA and Japan, under high latitudes. In tropical and poorer countries, these patients are typically, and unfortunately, unattended. Difficulties in diagnosis, including the lack of information from local medical dermatologists and complications in obtaining appropriate rigorous photoprotection, are just some of the problems faced by these patients and families.

Most of the reports of gene identification and attention to XP families in these countries depend on studies performed in USA or Europe. These studies showed interesting data of genetic clusters, such as the one identified in Guatemala for an isolated community, where 12 children carried a new mutation in the XPC gene, likely reflecting consanguineous marriage (Cleaver et al., 2007). Another genetic cluster was also recently described in patients from a French Comorian Island near the Indian Ocean in West Africa. Among the black Mayotte population, more than 32 XP patients carried a mutation in the XPC gene (Cartault et al., 2011), likely resulting from a founder effect from the African continent. Although black skin protects these patients, these individuals still suffer from the heavy sunlight intensity, with the development of skin tumors and early ocular injuries. Another important finding was the prevalence of a specific mutation (c.1643_1644delTG, p.Val548AlafsX25) in the XPC gene in North Africa. This mutation was observed in $87 \%$ of the XP-C patients in this location, primarily in unrelated families, reflecting a founder mutation aging 50 generations or 1250 years (Soufir et al., 2010). It is curious how this deleterious mutation can still be observed, despite a strong negative selection, especially in these sunny environments. Certainly, the mutated allele is kept in heterozygote individuals, as they present normal repair phenotype.

Recently, evidence has been obtained from the direct assistance of patients in the tropical countries, showing sporadic cases (Halpern et al., 2008) and more complete studies in the genetic identification of mutations (mostly 
novel) in XPC (Leite et al., 2009), XPV (Ortega-Recalde et al., 2013) and XPG (Soltys et al., 2013) genes. One of the mutations described for the XPC gene in Brazil (Leite et al., 2009 ) is the same as the highly prevalent mutation reported in North Africa (Soufir et al., 2010), indicating the potential migration from Africa to Europe and subsequently to Brazil (likely from Portugal). The two novel XPG missense mutations observed in the two siblings in Brazil were shown to produce proteins with low repair of UV-photoproducts, but normal repair of lesions generated through oxidative stress, likely explaining the mild phenotype of these patients (Soltys et al., 2013). Moreover, a pioneering effort for the systematic identification of mutations that affect XPC and XPA genes has recently been underway in Brazilian patients, and these results will contribute to both the assistance to these patients and the scientific knowledge on the distribution of these pathological mutations (K. Santiago and MI Achatz, unpublished data). Interestingly, among those XP patients some have a Native American Indian ori- gin, as the XP community described in Guatemala (Cleaver et al., 2007) and the XP severely affected children belonging to the Navajo Reservation in Southwest of USA (http://globalgenes.org/xeroderma-pigmentosum-suddenlyarises-on-navajo-reservation/). Most likely, these will not be the only cases for Native Americans, suggesting mutated alleles of XP genes, causing the disease, have possibly existed before the human migration to the Americas, from Asia.

Moreover, another genetic cluster has been reported in the Brazilian state of Goias (a sunny central area of this country), with more than 20 affected XP patients diagnosed in an isolated community (Chaibub, 2011). Genetic identification of the mutation is underway, and preliminary data indicate that the XPV gene is affected in this population (unpublished results).

\section{Conclusions and Perspectives}

The wide spectrum of symptoms and diseases caused by NER deficiency reflects the relevance of this repair

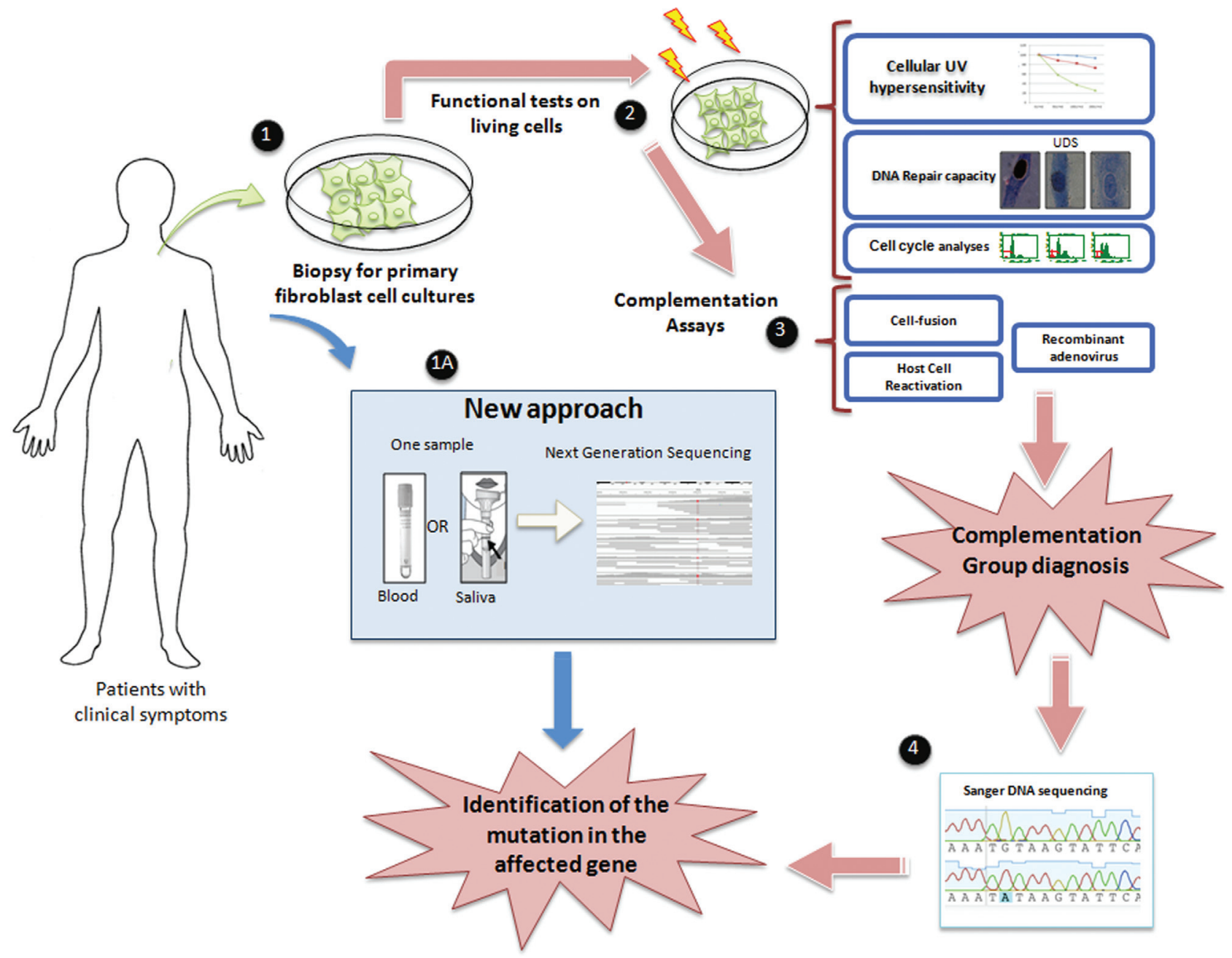

Figure 5 - Strategies for molecular diagnosis of XP patients. Identification of XP gene mutation based on a series of biological and biochemical assays using primary cells obtained from patient skin biopsies. Although the information from these cells has always been rich, the direct sequencing of DNA repair genes using next generation sequencing techniques may facilitate the molecular diagnosis using blood or saliva samples. 
pathway in the maintenance of genome stability in humans. Since 1968, the molecular defects affecting XP patients and other syndromes have been described. Studies with cells from these patients have contributed to our current understanding of the causes of cancer and the development of tools to fight tumors (Moraes et al., 2012). We have also learned a great deal concerning aging, which might improve the health and quality of life of the elderly. Thus, the human society is indebted to NER-defective patients, although little can really be done to help them. Gene therapy for these patients is at its infancy (Magnaldo and Sarasin, 2004; Menck et al., 2007), and not even the simple identification of the genetic mutation is provided in many countries worldwide, particularly in developing countries. This identification could, at least, provide some prognosis for the disease and support for genetic counseling for the affected families. Until recently, there was a strong need for biological essays for the identification of the genetic complementation group in XP patients, requiring skin biopsies, which are painful for the patient, and cell culture, which is time consuming and requires specific skills. The direct sequencing of exomes (Ortega-Recalde et al., 2013) or specific genes using next generation sequencing techniques of DNA isolated directly from saliva samples provides an excellent opportunity for the rapid diagnosis of these mutations (Figure 5). Thus, new horizons may bring hope for the $\mathrm{XP}$ patients and their families.

\section{Acknowledgments}

This work was financially supported through grants from the Fundação de Amparo à Pesquisa do Estado de São Paulo (FAPESP) and Conselho Nacional de Desenvolvimento Científico e Tecnológico (CNPq).

\section{References}

Aamann MD, Sorensen MM, Hvitby C, Berquist BR, Muftuoglu M, Tian J, de Souza-Pinto NC, Scheibye-Knudsen M, Wilson 3rd DM, Stevnsner T, et al. (2010) Cockayne syndrome group B protein promotes mitochondrial DNA stability by supporting the DNA repair association with the mitochondrial membrane. FASEB J 24:2334-2346.

Amiel A, Peretz G, Slor H, Weinstein G and Fejgin MD (2004) Molecular cytogenetic parameters in fibroblasts from patients and carriers of xeroderma pigmentosum. Cancer Genet Cytogenet 149:154-160.

Andrade LN, Nathanson JL, Yeo GW, Menck CF and Muotri AR (2012) Evidence for premature aging due to oxidative stress in iPSCs from Cockayne syndrome. Hum Mol Genet 21:3825-3834.

Andressoo JO and Hoeijmakers JH (2005) Transcription-coupled repair and premature ageing. Mutat Res 577:179-194.

Andrews AD, Barrett SF and Robbins JH (1976) Relation of DNA repair processes to pathological ageing of the nervous system in xeroderma pigmentosum. Lancet 19:1318-1320.

Andrews AD, Barrett SF, Yoder FW and Robbins JH (1978a) Cockayne's syndrome fibroblasts have increased sensitivity to ultraviolet light but normal rates of unscheduled DNA synthesis. J Invest Dermatol 70:237-239.

Andrews AD, Barrett SF and Robbins JH (1978b) Xeroderma pigmentosum neurological abnormalities correlate with colony-forming ability after ultraviolet radiation. Proc Natl Acad Sci USA 75:1984-1988.

Balajee AS, May A, Dianov GL, Friedberg EC and Bohr VA (1997) Reduced RNA polymerase II transcription in intact and permeabilized Cockayne syndrome group B cells. Proc Natl Acad Sci USA 94:4306-4311.

Batista LF, Kaina B, Meneghini R and Menck CF (2009) How DNA lesions are turned into powerful killing structures: Insights from UV-induced apoptosis. Mutat Res 681:197-208.

Berra CM, Oliveira CS, Garcia CCM, Rocha CRR, Lerner LK, Andrade LCL, Baptista MS and Menck CFM (2013) Nucleotide excision repair activity on DNA damage induced by photoactivated methylene blue. Free Radic Biol Med 61C:343-356.

Bodak N, Queille S, Avril MF, Bouadjar B, Drougard C, Sarasin A and Daya-Grosjean L (1999) High levels of patched gene mutations in basal-cell carcinomas from patients with xeroderma pigmentosum. Proc Natl Acad Sci USA 96:51175122.

Bohr VA, Smith CA, Okumoto DS and Hanawalt PC (1985) DNA repair in an active gene: Removal of pyrimidine dimers from the DHFR gene of CHO cells is much more efficient than in the genome overall. Cell 40:359-369.

Boulikas T (1996) Xeroderma pigmentosum and molecular cloning of DNA repair genes. Anticancer Res 16:693-708.

Brooks PJ (2013) Blinded by the UV light: How the focus on transcription-coupled NER has distracted from understanding the mechanisms of Cockayne syndrome neurologic disease. DNA Repair 12:656-671.

Cadet J, Mouret S, Ravanat JL and Douki T (2012) Photoinduced damage to cellular DNA: Direct and photosensitized reactions. Photochem Photobiol 88:1048-1065.

Cartault F, Nava C, Malbrunot AC, Munier P, Hebert JC, N'guyen P, Djeridi N, Pariaud P, Pariaud J, Dupuy A, et al. (2011) A new XPC gene splicing mutation has lead to the highest worldwide prevalence of xeroderma pigmentosum in black Mahori patients. DNA Repair 10:577-585.

Chaibub SCW (2011) High incidence of xeroderma pigmentosum in a countryside community in the state of Goiás, Brazil. Surg Cosmet Dermatol 3:112-115.

Cleaver JE (1968) Defective repair replication of DNA in xeroderma pigmentosum. Nature 218:652-656.

Cleaver JE (2000) Common pathways for ultraviolet skin carcinogenesis in the repair and replication defective groups of xeroderma pigmentosum. J Dermatol Sci 23:1-11.

Cleaver JE, Feeney L, Tang JY and Tuttle P (2007) Xeroderma pigmentosum group $\mathrm{C}$ in an isolated region of Guatemala. $\mathrm{J}$ Invest Dermatol 127:493-496.

Cleaver JE, Bezrookove V, Revet I and Huang EJ (2013) Conceptual developments in the causes of Cockayne syndrome. Mech Ageing 134:284-290.

Cockayne EA (1936) Dwarfism with retinal atrophy and deafness. Arch Dis Child 11:1-8.

Colella S, Nardo T, Botta E, Lehmann AR and Stefanini M (2000) Identical mutations in the CSB gene associated with either Cockayne syndrome or the DeSanctis-cacchione variant of xeroderma pigmentosum. Hum Mol Genet 9:1171-1175. 
Compe E and Egly JM (2012) TFIIH: When transcription met DNA repair. Nat Rev Mol Cell Biol 13:343-354.

Cortat B, Garcia CMC, Quinet A, Schuch AP, de Lima-Bessa KM and Menck CF (2013) The relative roles of DNA damage induced by UVA irradiation in human cells. Photochem Photobiol Sci 12:1483-1495.

Costa RM, Chiganças V, Galhardo R da S, Carvalho H and Menck CF (2003) The eukaryotic nucleotide excision repair pathway. Biochimie 85:1083-1099.

De Weerd-Kastelein EA, Keijzer W and Bootsma D (1972) Genetic heterogeneity of xeroderma pigmentosum demonstrated by somatic cell hybridization. Nat New Biol 238:8083.

D’Errico M, Calcagnile A, Canzona F, Didona B, Posteraro P, Cavalieri R, Corona R, Vorechovsky I, Nardo T, Stefanini M, et al. (2000) UV mutation signature in tumor suppressor genes involved in skin carcinogenesis in xeroderma pigmentosum patients. Oncogene 19:463-467.

D’Errico M, Parlanti E, Teson M, de Jesus BM, Degan P, Calcagnile A, Jaruga P, Bjørås M, Crescenzi M, Pedrini AM, et al. (2006) New functions of XPC in the protection of human skin cells from oxidative damage. EMBO J 25:4305-4315.

D’Errico M, Parlanti E, Teson M, Degan P, Lemma T, Calcagnile A, Iavarone I, Jaruga P, Ropolo M, Pedrini AM, et al. (2007) The role of CSA in the response to oxidative DNA damage in human cells. Oncogene 26:4336-4343.

Diderich K, Alanazi M and Hoeijmakers JH (2011) Premature aging and cancer in nucleotide excision repair-disorders. DNA Repair 10:772-780.

DiGiovanna JJ and Kraemer KH (2012) Shining a light on xeroderma pigmentosum. J Invest Dermatol 132:785-796.

Douki T, Reynaud-Angelin A, Cadet J and Sage E (2003) Bipyrimidine photoproducts rather than oxidative lesions are the main type of DNA damage involved in the genotoxic effect of solar UVA radiation. Biochemistry 42:9221-9226.

DeSanctis C and Cacchione AI (1932) Idiozia xerodermia. Riv Sper Freniat 56:269-292.

Dumaz N, Drougard C, Sarasin A and Daya-Grosjean L (1993) Specific UV-induced mutation spectrum in the p53 gene of skin tumors from DNA-repair-deficient xeroderma pigmentosum patients. Proc Natl Acad Sci USA 90:10529-10533.

Fagbemi AF, Orelli B and Schärer OD (2011) Regulation of endonuclease activity in human nucleotide excision repair. DNA Repair 10:722-729.

Giglia G, Dumaz N, Drougard C, Avril MF, Daya-Grosjean L and Sarasin A (1998) p53 mutations in skin and internal tumors of xeroderma pigmentosum patients belonging to the complementation group C. Cancer Res 58:4402-4409.

Giglia-Mari G, Coin F, Ranish JA, Hoogstraten D, Theil A, Wijgers N, Jaspers NG, Raams A, Argentini M, van der Spek PJ, et al. (2004) A new, tenth subunit of TFIIH is responsible for the DNA repair syndrome trichothiodystrophy group A. Nat Genet 36:714-719.

Giglia-Mari G and Sarasin A (2003) TP53 mutations in human skin cancers. Hum Mutat 21:217-228.

Goss JR, Stolz DB, Robinson AR, Zhang M, Arbujas N, Robbins PD, Glorioso JC and Niedernhofer LJ (2011) Premature aging-related peripheral neuropathy in a mouse model of progeria. Mech Ageing Dev 132:437-442.
Gredilla R, Garm C and Stevnsner T (2012) Nuclear and mitochondrial DNA repair in selected eukaryotic aging model systems. Oxid Med Cell Longev 2012:282438.

Halpern J, Hopping B and Brostoff JM (2008) Photosensitivity, corneal scarring and developmental delay: Xeroderma pigmentosum in a tropical country. Cases J 1:254.

Hanawalt PC (2001) Revisiting the rodent repairadox. Environ Mol Mutagen 38:89-96.

Hebra F and Kaposi M (1874) On diseases of the skin including exanthemata, volume III. The New Sydenham Society 61:252-258.

Hirai Y, Kodama Y, Moriwaki S, Noda A, Cullings HM, Macphee DG, Kodama K, Mabuchi K, Kraemer KH, Land CE, et al. (2006) Heterozygous individuals bearing a founder mutation in the XPA DNA repair gene comprise nearly $1 \%$ of the Japanese population. Mutat Res 601:171-178.

Horibata K, Iwamoto Y, Kuraoka I, Jaspers NG, Kurimasa A, Oshimura M, Ichihashi M and Tanaka K (2004) Complete absence of Cockayne syndrome group $\mathrm{B}$ gene product gives rise to UV-sensitive syndrome but not Cockayne syndrome. Proc Natl Acad Sci USA 101:15410-15415.

Iyama T and Wilson 3rd DM (2013) DNA repair mechanisms in dividing and non-dividing cells. DNA Repair 12:620-636.

Jaarsma D, van der Pluijm I, van der Horst GT and Hoeijmakers JH (2013) Cockayne syndrome pathogenesis: Lessons from mouse models. Mech Ageing Dev 134:180-195.

Kannouche P and Stary A (2003) Xeroderma pigmentosum variant and error-prone DNA polymerases. Biochimie 85:1123-1132.

Kassam SN and Rainbow AJ (2007) Deficient base excision repair of oxidative DNA damage induced by methylene blue plus visible light in xeroderma pigmentosum group C fibroblasts. Biochem Biophys Res Commun 359:1004-1009.

Kashiyama K, Nakazawa Y, Pilz DT, Guo C, Shimada M, Sasaki K, Fawcett H, Wing JF, Lewin SO, Carr L, et al. (2013) Malfunction of nuclease ERCC1-XPF results in diverse clinical manifestations and causes Cockayne syndrome, xeroderma pigmentosum, and Fanconi anemia. Am J Hum Genet 92:807-819.

Kim H and D'Andrea AD (2012) Regulation of DNA cross-link repair by the Fanconi anemia /BRCA pathway. Genes Dev 26:1393-1408.

Kleijer WJ, Laugel V, Berneburg M, Nardo T, Fawcett H, Gratchev A, Jaspers NG, Sarasin A, Stefanini M and Lehmann AR (2008) Incidence of DNA repair deficiency disorders in western Europe: Xeroderma pigmentosum, Cockayne syndrome and trichothiodystrophy. DNA Repair 7:744-750.

Knoch J, Kamenisch Y, Kubisch C and Berneburg M (2012) Rare hereditary diseases with defects in DNA-repair. Eur J Dermatol 22:443-455.

Kirkali G, de Souza-Pinto NC, Jaruga P, Bohr VA and Dizdaroglu M (2009) Accumulation of (5'S)-8,5'-cyclo-2'-deoxyadenosine in organs of Cockayne syndrome complementation group B gene knockout mice. DNA Repair 8:274-278.

Kraemer KH, Andrews AD, Barrett SF and Robbins JH (1976) Colony-forming ability of ultraviolet-irradiated xeroderma pigmentosum fibroblasts from different DNA repair complementation groups. Biochim Biophys Acta 442:147-153.

Kraemer KH, Lee MM, Andrews AD and Lambert WC (1994) The role of sunlight and DNA repair in melanoma and 
nonmelanoma skin cancer. The xeroderma pigmentosum paradigm. Arch Dermatol 130:1018-1021.

Lehmann AR (1982) Three complementation groups in Cockayne syndrome. Mutat Res 106:347-356.

Lehmann AR (2003) DNA repair-deficient diseases, xeroderma pigmentosum, Cockayne syndrome and trichothiodystrophy. Biochimie 85:1101-1111.

Lehmann AR, Kirk-Bell S, Arlett CF, Paterson MC, Lohman PH, de Weerd-Kastelein EA and Bootsma D (1975) Xeroderma pigmentosum cells with normal levels of excision repair have a defect in DNA synthesis after UV-irradiation. Proc Natl Acad Sci USA 72:219-223.

Lehmann AR, McGibbon D and Stefanini M (2011) Xeroderma pigmentosum. Orphanet J Rare Dis 6:70.

Leite RA, Marchetto MC, Muotri AR, Vasconcelos D de M, de Oliveira ZN, Machado MCR and Menck CF (2009) Identification of XP complementation groups by recombinant adenovirus carrying DNA repair genes. J Invest Dermatol 129:502-506.

Magnaldo T and Sarasin A (2004) Xeroderma pigmentosum: From symptoms and genetics to gene-based skin therapy. Cells Tissues Organs 177:189-198.

Masutani C, Hanaoka F and Ahmad SI (2008) Xeroderma pigmentosum variant, $\mathrm{XP}-\mathrm{V}$ : Its product and biological roles. Adv Exp Med Biol 637:93-102.

Menck CF, Armelini MG and Lima-Bessa KM (2007) On the search for skin gene therapy strategies of xeroderma pigmentosum disease. Curr Gene Ther 7:163-174.

Marinoglou K (2012) The role of the DNA damage response kinase ataxia telangiectasia mutated in neuroprotection. Yale J Biol Med 85:469-480.

Mayne LV and Lehmann AR (1982) Failure of RNA synthesis to recover after UV irradiation: An early defect in cells from individuals with Cockayne's syndrome and xeroderma pigmentosum. Cancer Res 42:1473-1478.

McKay BC, Becerril C and Ljungman M (2001) P53 plays a protective role against UV-and cisplatin-induced apoptosis in transcription-coupled repair proficient fibroblasts. Oncogene 20:6805-6808.

Mellon I, Spivak G and Hanawalt PC (1987) Selective removal of transcription-blocking DNA damage from the transcribed strand of the mammalian DHFR gene. Cell 51:241-249.

Menoni H, Hoeijmakers JH and Vermeulen W (2012) Nucleotide excision repair-initiating proteins bind to oxidative DNA lesions in vivo. J Cell Biol 199:1037-1046.

Moraes MC, Neto JB and Menck CF (2012) DNA repair mechanisms protect our genome from carcinogenesis. Front Biosci 17:1362-1388.

Moser J, Kool H, Giakzidis I, Caldecott K, Mullenders LH and Fousteri MI (2007) Sealing of chromosomal DNA nicks during nucleotide excision repair requires XRCC1 and DNA ligase III alpha in a cell-cycle-specific manner. Mol Cell 27:311-323.

Mullenders LH, van Kesteren van Leeuwen AC, van Zeeland AA and Natarajan AT (1988) Nuclear matrix associated DNA is preferentially repaired in normal human fibroblasts, exposed to a low dose of ultraviolet light but not in Cockayne's syndrome fibroblasts. Nucleic Acids Res 16:10607-10622.

Nardo T, Oneda R, Spivak G, Vaz B, Mortier L, Thomas P, Orioli D, Laugel V, Stary A, Hanawalt PC, et al. (2009) A UVsensitive syndrome patient with a specific CSA mutation re- veals separable roles for CSA in response to UV and oxidative DNA damage. Proc Natl Acad Sci USA 106:6209-6214.

Niedernhofer LJ, Garinis GA, Raams A, Lalai AS, Robinson AR, Appeldoorn E, Odijk H, Oostendorp R, Ahmad A, van Leeuwen W, et al. (2006) A new progeroid syndrome reveals that genotoxic stress suppresses the somatotroph axis. Nature 444:1038-1043.

Niedernhofer LJ, Bohr VA, Sander M and Kraemer KH (2011) Xeroderma pigmentosum and other diseases of human premature aging and DNA repair: Molecules to patients. Mech Ageing Dev 132:340-347.

Oh DH and Spivak G (2010) Hereditary photodermatoses. Adv Exp Med Biol 685:95-105.

Ortega-Recalde O, Vergara JI, Fonseca DJ, Ríos X, Mosquera H, Bermúdez OM, Medina CL, Vargas CI, Pallares AE, Restrepo CM and Laissue P (2013) Whole-exome sequencing enables rapid determination of xeroderma pigmentosum molecular etiology. PLoS One 8:e64692.

Osterod M, Larsen E, Le Page F, Hengstler JG, Van Der Horst GT, Boiteux S, Klungland A and Epe B (2002) A global DNA repair mechanism involving the Cockayne syndrome $\mathrm{B}$ (CSB) gene product can prevent the in vivo accumulation of endogenous oxidative DNA base damage. Oncogene 21:8232-8239.

Parris CN and Kraemer KH (1993) Ultraviolet-induced mutations in Cockayne syndrome cells are primarily caused by cyclobutane dimer photoproducts while repair of other photoproducts is normal. Proc Natl Acad Sci USA 90:7260-7264.

Pascucci B, Lemma T, Iorio E, Giovannini S, Vaz B, Iavarone I, Calcagnile A, Narciso L, Degan P, Podo F, et al. (2012) An altered redox balance mediates the hypersensitivity of Cockayne syndrome primary fibroblasts to oxidative stress. Aging Cell 11:520-529.

Quinet A, Vessoni AT, Rocha CR, Gottifredi V, Biard D, Sarasin A, Menck CF and Stary A (2014) Gap-filling and bypass at the replication fork are both active mechanisms for tolerance of low-dose ultraviolet-induced DNA damage in the human genome. DNA Repair 14:27-38.

Robbins JH, Kraemer KH, Lutzner MA, Festoff BW and Coon HG (1974) Xeroderma pigmentosum: An inherited disease with sun-sensitivity, multiple cutaneous neoplasms, and abnormal DNA repair. Ann Internal Med 80:221-248.

Sale JE, Lehmann AR and Woodgate R (2012) Y-family DNA polymerases and their role in tolerance of cellular DNA damage. Nat Rev Mol Cell Biol 13:141-152.

Sale JE (2013) Translesion DNA synthesis and mutagenesis in eukaryotes. Cold Spring Harb Perspect Biol 5:a012708.

Scheibye-Knudsen M, Ramamoorthy M, Sykora P, Maynard S, Lin PC, Minor RK, Wilson 3rd DM, Cooper M, Spencer R, de Cabo R, et al. (2012) Cockayne syndrome group B protein prevents the accumulation of damaged mitochondria by promoting mitochondrial autophagy. J Exp Med 209:855869.

Schmickel RD, Chu EH, Trosko JE and Chang CC (1977) Cockayne syndrome: A cellular sensitivity to ultraviolet light. Pediatrics 60:135-139.

Schuch AP, Yagura T, Makita K, Yamamoto H, Schuch NJ, Agnez-Lima LF, Macmahon RM and Menck CF (2012) DNA damage profiles induced by sunlight at different latitudes. Environ Mol Mutagen 53:98-206. 
Schuch AP, Garcia CCM, Makita K and Menck CF (2013) DNA damage as a biological sensor for environmental sunlight. Photochem Photobiol Sci 12:1259-1272.

Schwertman P, Lagarou A, Dekkers DH, Raams A, van der Hoek AC, Laffeber C, Hoeijmakers JH, Demmers JA, Fousteri M, Vermeulen W, et al. (2012) UV-sensitive syndrome protein UVSSA recruits USP7 to regulate transcription-coupled repair. Nat Genet 44:598-602.

Sepe S, Payan-Gomez C, Milanese C, Hoeijmakers JH and Mastroberardino PG (2013) Nucleotide excision repair in chronic neurodegenerative diseases. DNA Repair 12:568577.

Shiloh Y and Ziv Y (2013) The ATM protein kinase: Regulating the cellular response to genotoxic stress, and more. Nat Rev Mol Cell Biol 14:197-210.

Soltys DT, Rocha CR, Lerner LK, de Souza TA, Munford V, Cabral F, Nardo T, Stefanini M, Sarasin A, Cabral-Neto JB, et al. (2013) Novel XPG (ERCC5) mutations affect DNA repair and cell survival after ultraviolet but not oxidative stress. Hum Mutat 34:481-489.

Soufir N, Ged C, Bourillon A, Austerlitz F, Chemin C, Stary A, Armier J, Pham D, Khadir K, Roume J, et al. (2010) A prevalent mutation with founder effect in xeroderma pigmentosum group $\mathrm{C}$ from north Africa. J Invest Dermatol 130:1537-1542.

Spivak G (2005) UV-sensitive syndrome. Mutat Res 577:162169.

Spivak G and Hanawalt PC (2006) Host cell reactivation of plasmids containing oxidative DNA lesions is defective in Cockayne syndrome but normal in UV-sensitive syndrome fibroblasts. DNA Repair 5:13-22.

Stefanini M, Botta E, Lanzafame M and Orioli D (2010) Trichothiodystrophy: From basic mechanisms to clinical implications. DNA Repair 9:2-10.

Stevnsner T, Nyaga S, de Souza-Pinto NC, van der Horst GT, Gorgels TG, Hogue BA, Thorslund T and Bohr VA (2002) Mitochondrial repair of 8 -oxoguanine is deficient in Cockayne syndrome group B. Oncogene 21:8675-8682.

Suzumura H and Arisaka O (2010) Cerebro-oculo-facio-skeletal syndrome. Adv Exp Med Biol 685:210-214.

Tuo J, Müftüoglu M, Chen C, Jaruga P, Selzer RR, Brosh Jr RM, Rodriguez H, Dizdaroglu M and Bohr VA (2001) The Cockayne Syndrome group B gene product is involved in general genome base excision repair of 8-hydroxyguanine in DNA. J Biol Chem 276:45772-45779.

Tuo J, Jaruga P, Rodriguez H, Bohr VA and Dizdaroglu M (2003) Primary fibroblasts of Cockayne syndrome patients are defective in cellular repair of 8-hydroxyguanine and 8-hydroxyadenine resulting from oxidative stress. FASEB J 17:668-674.

van der Horst GT, van Steeg H, Berg RJ, van Gool AJ, de Wit J, Weeda G, Morreau H, Beems RB, van Kreijl CF, de Gruijl FR, et al. (1997) Defective transcription-coupled repair in Cockayne syndrome B mice is associated with skin cancer predisposition. Cell 89:425-435.

van der Horst GT, Meira L, Gorgels TG, de Wit J, Velasco-Miguel S, Richardson JA, Kamp Y, Vreeswijk MP, Smit B, Bootsma D, et al. (2002) UVB radiation-induced cancer predisposition in Cockayne syndrome group A (CSA) mutant mice. DNA Repair 1:143-157.

van Steeg H and Kraemer KH (1999) Xeroderma pigmentosum and the role of UV-induced DNA damage in skin cancer. Mol Med Today 52:86-94.

Vélez-Cruz R and Egly JM (2013) Cockayne syndrome group B (CSB) protein: At the crossroads of transcriptional networks. Mech Ageing Dev 134:234-242.

Venema J, Mullenders LH, Natarajan AT, van Zeeland AA and Mayne LV (1990) The genetic defect in Cockayne syndrome is associated with a defect in repair of UV-induced DNA damage in transcriptionally active DNA. Proc Natl Acad Sci USA 87:4707-4711.

Vreeswijk MP, Overkamp MW, Westland BE, van HeesStuivenberg S, Vrieling H, Zdzienicka MZ, van Zeeland AA and Mullenders LH (1998) Enhanced UV-induced mutagenesis in the UV61 cell line, the Chinese hamster homologue of Cockayne's syndrome B, is associated with defective transcription coupled repair of cyclobutane pyrimidine dimers. Mutat Res 409:49-56.

Zhang X, Horibata K, Saijo M, Ishigami C, Ukai A, Kanno S, Tahara H, Neilan EG, Honma M, Nohmi T, et al. (2012) Mutations in UVSSA cause UV-sensitive syndrome and destabilize ERCC6 in transcription-coupled DNA repair. Nat Genet 44:593-597.

License information: This is an open-access article distributed under the terms of the Creative Commons Attribution License, which permits unrestricted use, distribution, and reproduction in any medium, provided the original work is properly cited. 